\title{
Predictive Factors for Intraabdominal Hypertension after Incisional Hernia Repair
}

\author{
Marius Coțofană ${ }^{1,2}$, Florentina Mușat ${ }^{1,2}$, Dan Nicolae Păduraru ${ }^{1,2}$, Octavian Andronic ${ }^{1,2}$, Alexandra Bolocan $^{1,2}$, Daniel Ion ${ }^{1,2}$ \\ 'The University of Medicine and Pharmacy "Carol Davila", Bucharest, Romania \\ ${ }^{2}$ The Emergency University Hospital of Bucharest, Romania
}

Corresponding author:

Dan Nicolae Păduraru, MD

The University of Medicine and

Pharmacy "Carol Davila", Bucharest

The Emergency University Hospital

of Bucharest, Romania

Email: dan.paduraru.nicolae@gmail.com

\section{Rezumat}

Factori predispozanț pentru aparitia hipertensiunii intra-abdominale în urma curei chirurgicale a herniilor incizionale

Acest review de literatură îşi propune să sintetizeze factorii de risc care predispun la apariția hipertensiunii intraabdominale în urma curei chirurgicale a herniilor incizionale. Cercetarea noastră a utilizat platformele de cercetare Web of Science, Scopus şi PubMed şi a utilizat ca formulă de căutare: ("Intraabdominal hypertension" OR "intraabdominal pressure" OR "abdominal compartiment syndrome") AND "risk factors" AND "incisional hernia". Filtrarea rezultatelor s-a realizat după următoarele criterii: limba: engleză, publish year > 2000 şi acces: in extenso. În acest context, am ales să împărțim factorii de risc pentru creşterea PIA în următoarele categorii: cei legați de habitusul şi antropometria corpului; cei asociați cu prezența comorbidităților; cei legați de caracteristicile defectului (eventrației) din peretele abdominal; cei asociați actului chirurgical. Printre cei mai importanți pot fi amintiți: indicele de masă corporală, BPOC, eventrațiile de dimensiuni mari cu pierderea dreptului la domiciliu, tehnica chirurgicală utilizată, timpul operator prelungit şi tentative repetate de închidere a defectului.

Cuvinte cheie: hipertensiune intraabdominală, hernie incizională, complicațiile reconstrucției peretelui abdominal, factori de risc

\section{Abstract}

The purpose of our research is to synthesize the risk factors 
quoted in the literature which predispose to intra-abdominal hypertension occurrence following surgical repair of incisional hernias. We used for our research the Web of Science, Scopus and PubMed research platforms and we used the following search formula: ("Intra-abdominal hypertension" OR "intra-abdominal pressure" OR "abdominal compartment syndrome") AND "risk factors" AND "incisional hernia". The results were filtered according to the following criteria: language (English), publish year (>2000) and access (in extenso). In this context, we chose to classify the risk factors for IAP increase in the following categories: (1) those related body habitus and anthropometry; (2) those associated with the presence of comorbidities; (3) those related to the defect of the abdominal wall; (4) those associated with the surgical management. Among the most important risk factors we mention: elevated BMI, chronic obstructive pulmonary disease, large incisional hernias with loss of domain, surgical technique used, prolonged surgeries and repeated attempts to close the defect.

Key words: intra-abdominal hypertension, intra-abdominal pressure, abdominal compartment syndrome, risk factors, incisional hernia

\section{Introduction}

Intra-abdominal hypertension (IAH) is defined by the World Society of the Abdominal Compartment Syndrome $(1,2)$ as an increase in intra-abdominal pressure (IAP) above $12 \mathrm{mmHg}$ which can evolve to abdominal compartment syndrome (ACS) when the threshold of 20 $\mathrm{mmHg}$ is exceeded and multiple organ failure is associated. Patients at risk of developing IAH/ACS can be divided into two categories: patients who suffer an increase of the intraabdominal content volume and patients with decreased abdominal volume (management of abdominal wall defects). Both groups can be characterized by an increase of the IAP values, but patients in the first category are prone to further decompensation subsequently to ischemia-reperfusion injuries in the mesenteric area accompanied by the need for hydric resuscitation [IAH occurs in about $40 \%$ of the intensive care unit patients (3)]. This type of evolution can only further increase the degree of edema and consequently leads to the intolerance of IAP rise. With regard to the second group, there is a small number of studies reporting IAH/ACS as a complication of abdominal wall reconstruction surgeries. This can be explained by the fact that signs of IAH can occur after repairing the abdominal wall defects, but these are transient, considered even physiological, and resolute without causing major management problems (4-7). The topic of this article is a relevant one taking into account that the comorbidities of the patient play an important role in the management of abdominal wall defects and the fact that difficult incisional hernias can be successfully surgically approached using current alloplastic techniques $(8,9)$. The purpose of our research is to synthesize the risk factors quoted in the literature which predispose to IAH occurrence following surgical repair of incisional hernias.

\section{Materials and Method}

We used for our research the Web of Science, Scopus and PubMed research platforms and we used the following search formula: ("Intraabdominal hypertension" OR "intra-abdominal pressure" OR "abdominal compartment syndrome") AND "risk factors" AND "incisional hernia". The results were filtered according to the following criteria: language (English), publish year (>2000) and access (in extenso).

\section{Results and Discussions}

A very important parameter for understanding the pathophysiological mechanism of IAH is abdominal compliance (AC) expressed as the 
ration between the variation of intra-abdominal volume (IAV) and of the IAP. AC designates the abdominal expansion capacity and it is determined by the elasticity of the expandable limits of the abdominal cavity which are the abdominal wall and the diaphragm. Specifically, in a patient with normal AC, a $2 \mathrm{~L}$ basal IAV increase will generate a small change in the same direction of IAP by about $5 \mathrm{mmHg}$. In the case of a patient with low AC, the same variation of IAV produces an increase in IAP by $15 \mathrm{mmHg}$ (10). Thus, all circumstances in which AC is altered will lead to a higher risk of IAH/ACS.

In this context, we chose to classify the risk factors for IAP increase in the following categories: (1) those related body habitus and anthropometry; (2) those associated with the presence of comorbidities; (3) those related to the defect of the abdominal wall; (4) those associated with the surgical management.

\section{Anthropometric and Demographic Risk Factors}

Remodeling capacity of the shape of the abdominal cavity depends on certain factors such as height, weight, body mass index (BMI), age, sex and fat distribution (Table 1). For patients with android obesity and significant visceral adiposity, the abdominal cavity has a spherical shape and a low expansion capacity. For those with gynoid obesity, adipose tissue is better represented subcutaneously, the abdominal perimeter is elliptical and the $\mathrm{AC}$ is increased (10). It is worth mentioning the observation of a study (14)

Table 1. Anthropometric and demographic risk factors

\begin{tabular}{lc}
\hline Risk factor & References \\
\hline Android obesity & $(6)$ \\
\hline Waist-to-hip ratio $>1$ & $(10)$ \\
\hline Increased visceral fat & $(11)$ \\
\hline Short stature & $(12)$ \\
\hline Male sex & $(12),(13)$ \\
\hline Young age & $(12)$ \\
\hline Obesity (weight, BMI) & $(6),(14),(15)$ \\
\hline
\end{tabular}

showing that the mean BMI of patients who developed postoperative IAH was $42 \mathrm{~kg} / \mathrm{m}^{2}$ versus $35,8 \mathrm{~kg} / \mathrm{m}^{2}$ in those who did not have this complication. The same correlation was valid for patients with ACS. They had an average BMI of $43 \mathrm{~kg} / \mathrm{m}^{2}$, compared to an average BMI of $36.5 \mathrm{~kg} / \mathrm{m}^{2}$ of those without ACS. In young patients, the elastic recoil of the abdominal wall is increased and it influences negatively the AC (12).

\section{Risk Factors Associated with the Presence of Comorbidities}

Comorbidities can play an important role in the development of IAH even if the most advantageous surgical technique is used for preventing an increase in the intra-abdominal pressure. Thus, two cases in which ACS occurred following surgical treatment using components separation techniques of giant incisional hernias have been reported $(16,17)$. This procedure has the advantage of allowing a tension free closure of large abdominal defects after increasing the IAV. However, despite using this technique, authors claim that comorbidities such as smoker status, asthma, obstructive sleep apnea contributed to the development of IAH in those two cases.

In another study (6), from 50 patients treated surgically for incisional hernias with a mean diameter of $14 \pm 5.8 \mathrm{~cm}, 92 \%$ were diagnosed postoperative with IAH and 16\% with ACS. It is also worth mentioning that the average BMI in this group was $34.6 \pm 6.7 \mathrm{~kg} / \mathrm{m}^{2}$ and that half of the patients had a significant history of obstructive sleep apnea (32\%), chronic obstructive pulmonary disease $(18 \%)$ or cirrhosis $(2 \%)$.

In the context of insufficient literature data related to risk factors strictly associated with hernia repair, it would be fair to admit that some of the general factors that predispose to IAH/ACS should also be taken into consideration (Table 2). Those factors are often responsible for primary or secondary IAH/ACS, but could also predispose to IAH/ACS as postoperative complications by altering the AC. 
Table 2. Factors associated with the presence of comorbidities. [Any change in the intraabdominal volume leads to a modification in the same direction of the IAP. Thoracic cavity pressure influence and can be influenced by the IAP (10)]

\begin{tabular}{lc}
\hline Risk factor & References \\
\hline Bowels and/or stomach filled with fluid & $(12)$ \\
\hline Splenomegaly & $(18)$ \\
\hline Hepatomegaly & $(18)$ \\
\hline Fluid overload & $(19-22)$ \\
\hline Tense ascites & $(12,22)$ \\
\hline Sepsis, burns, trauma and bleeding & $(18,23)$ \\
\hline Pseudocyst, abscess, abdominal fluid collections & $(21,24)$ \\
\hline Interstitial and anasarca edema (skin, abdominal wall) & $(23)$ \\
\hline Rectus sheath hematoma & $(12)$ \\
\hline Abdominal wall bleeding & $(23)$ \\
\hline Muscle contraction (pain) & $(12)$ \\
\hline Abdominal/thoracic burn eschars (circular) & $(23)$ \\
\hline Pneumoperitoneum & $(12)$ \\
\hline Mechanical ventilation (positive pressure) & $(21,22,25)$ \\
\hline Use of accessory muscles & $(12)$ \\
\hline Use of positive end-expiratory pressure (PEEP) & $(12,15)$ \\
\hline Tension pneumothorax & $(12,21)$ \\
\hline Chronic obstructive pulmonary disease; Asthma & $(16,17,26)$ \\
\hline Basal pleuropneumonia & $(12,25)$ \\
\hline
\end{tabular}

\section{Risk Factors Related to the Defect of the Abdominal Wall}

Multiple attempts of closing a defect can lead to fibrosis and tissue damage with a decrease in remodeling and adaptation to IAP variations capacity of the abdominal wall $(10,14)$ (Table 3).

Depending on the size of the defect, the incisional hernias can be small $(<5 \mathrm{~cm})$, medium $(5-10 \mathrm{~cm})$, large $(>10 \mathrm{~cm})$ and giant $(>10 \mathrm{~cm}$ and accompanied by loss of domain) (27). Loss of domain designates the case in which the ratio between the volume of the

Table 3. Risk factors related to the defect of the abdominal wall

\begin{tabular}{lc}
\hline Risk factor & References \\
\hline Diameter of the defect & $(5)$ \\
\hline Loss of domain & $(29)$ \\
\hline Ratio between the volume of the hernia sac & \\
and the volume of abdominal cavity & $(5,6)$ \\
\hline History of postoperative recurrence & $(10,14,30)$ \\
\hline
\end{tabular}

hernia sac and the volume of the abdominal cavity is $\geq 0.5$ (28). Patients with giant hernias have a significant risk of postoperative IAH/ ACS.

Palumbo et al (4) found a correlation between the size of the parietal defect, the IAP value 24 hours after its repair and the forced expiratory volume in the first second (FEV-1). Thus, in the postoperative evolution of 2 patients with $20 \mathrm{~cm}$ and $19 \mathrm{~cm}$ parietal defects, increasing in IAP by $9 \mathrm{mmHg}$ and 8 $\mathrm{mmHg}$ respectively have been recorded, accompanied by a decreasing in FEV- 1 by 300 $\mathrm{ml}$ and $200 \mathrm{ml}$. Although detailed studies involving a greater number of patients with a variety of incisional hernias are required, the authors suggest that variation in opposite directions of FEV-1 and IAP values can be used in early diagnosis of ACS.

In order to prevent this type of complications, Yao et al (5) correlated the ratio between the volume of the hernia sac and the volume of abdominal cavity (obtained by 3D CT reconstruction) with the risk of postoperative development of ACS. The highest ratio found in 10 patients studied was $7.82 \%$ and no case of ACS was reported. It is also worth mentioning that BMI values were in the range of $22-28 \mathrm{~kg} / \mathrm{m}^{2}$ and that defect diameters were less than $9 \mathrm{~cm}$. In another study, a $20 \%$ ratio was associated with postoperative IAH/ACS (6). The ratio between the volume of the hernia sac and the volume of the abdominal cavity which may predispose to ACS has not yet been established in literature. Investigating these features provides valuable information on the management of patients with important abdominal wall defects, but requires more detailed studies on a significant number of cases.

\section{Risk Factors Associated with the Surgical Management}

The dimensions, the material and the intraabdominal position of the prosthesis are equally important for prevention of IAH (Table 4). Regarding the prosthesis type, one study suggests that composite mesh can be 
Table 4. Risk factors associated with the surgical management

\begin{tabular}{lc}
\hline Risk factors & Reference \\
\hline Mesh dimension & $(16)$ \\
\hline Mesh type & $(16)$ \\
\hline Surgical technique & $(4,6,26)$ \\
\hline Surgery length & $(14)$ \\
\hline
\end{tabular}

successfully used in this context, (4) while other authors are in favor of using biological prosthesis made from non-cross-linked acellular collagen matrix derived from porcine dermis $(31,32)$. If this types of prosthesis are not available, one study recommends the use of an absorbable synthetic mesh (33). On the other hand, the use of prosthesis may limit postoperative the expansion of the abdominal cavity (16). Another variable that can influence patient evolution is the surgical technique chosen to repair the defect. Research has shown superior results of the intraperitoneal approach, fixation of the prosthesis with a spiral fixation device and use of the component separation (4) or transversusabdominis muscle release techniques (6). A recent study on 175 patients shows that prolonged surgeries have an increased risk of IAH/ACS because of the abundant hydric resuscitation [ $>5 \mathrm{~L}$ of fluid resuscitation over $24 \mathrm{~h}$, especially when crystalloid solutions are used (34)] that can lead to intestinal and abdominal wall edema (14).

\section{Conclusion}

This review assembles the risk factors that can predispose to IAH/ACS following incisional hernias surgical repair. Some of these factors are not supported by strong evidence from large, detailed trials, but more by case reports or small series of cases, so some observations may be subjective. Still, we chose to bring into attention those aspects because ACS/IAH can be easily overlooked, especially in the context of elective surgeries. Moreover, we chose to categorize the risk factors in order to emphasize that some of them should make a doctor adapt the preoperative care as well as the surgical plan and the surgical act itself. We believe that the limited number of studies on the subject of this article can be explained by several situations. Thus, for the majority of patients undergoing ventral hernia surgical repair, IAH is either underdiagnosed or it resolves without creating management difficulties. Also at this moment, some risk factors are hard to quantify (for example, calculating the abdominal volume by CT) and the number of patients who develop ACS in the context of hernia surgery associated with each individual risk factor is small in order to obtain statistically significant results.

The risk factors we found for these complications are related to the habitus and anthropometry, the presence of comorbidities, the characteristics of the hernia and the surgical act. Among the most important risk factors we mention: elevated BMI, COPD, large incisional hernias with loss of domain, surgical technique used, prolonged surgeries and repeated attempts to close the defect. Recent studies on larger number of patients demonstrate that IAH/ACS are real and serious complications. Awareness of the predisposing factors could be useful in predicting the occurrence of such complications after surgical cure of incisional hernia. Quantifying and standardizing these factors require more detailed studies.

Funding: Not applicable.

\section{Authors' Contributions}

All authors have contributed equally in writing, reading and approving the final manuscript.

\section{Ethics Approval and Consent to Participate:} Not applicable.

\section{Consent for publication: Not applicable.}

Competing interests: Not applicable.

\section{References}

1. Kirkpatrick AW, Roberts DJ, De Waele J, Jaeschke R, Malbrain MLNG, De Keulenaer B, et al. Intra-abdominal hypertension and the abdominal compartment syndrome: Updated consensus definitions and clinical practice guidelines from the World Society of the Abdominal Compartment Syndrome. In: Intensive Care Medicine. 
2013;39(7):1190-1206.

2. Malbrain MLNG, Cheatham ML, Kirkpatrick A, Sugrue M, Parr M, De Waele J, et al. Results from the International Conference of Experts on Intra-abdominal Hypertension and Abdominal Compartment Syndrome. I. Definitions. Intensive Care Med. 2006; 32(11):1722-32.

3. Maddison L, Starkopf J, Reintam Blaser A. Mild to moderate intraabdominal hypertension: Does it matter? World J Crit care Med. 2016;5(1):96-102.

4. Angelici AM, Perotti B, Dezzi C, Amatucci C, Mancuso G, Caronna $\mathrm{R}$, et al. Measurement of intra-abdominal pressure in large incisional hernia repair to prevent abdominal compartmental syndrome. G di Chir. 2016;37(1):31-6.

5. Yao S, Li JY, Liu F De, Pei LJ. Significance of measurements of herniary area and volume and abdominal cavity volume in the treatment of incisional hernia: Application of CT 3D reconstruction in 17 cases. Comput Aided Surg. 2012;17(1):40-5.

6. Petro CC, Raigani S, Fayezizadeh M, Rowbottom JR, Klick JC, Prabhu AS, et al. Permissible intraabdominal hypertension following complex abdominal wall reconstruction. In: Plastic and Reconstructive Surgery. 2015. 136(4):868-881.

7. A. W. Kirkpatrick, D. Nickerson, D. J. Roberts, M. J. Rosen PBM, C. C. Petro, Frederik Berrevoet, M. Sugrue, Jimmy Xiao CGB. Intraabdominal hypertension and abdominal compartment syndrome after abdominal wall reconstruction: quaternary syndromes? Scand J Surg. 2017;106(2):97-106.

8. Memon AA, Khan A, Zafar H, Murtaza G, Zaidi M. Repair of large and giant incisional hernia with onlay mesh: Perspective of a tertiary care hospital of a developing country. Int J Surg. 2013; 11(1):41-5.

9. Eriksson A, Rosenberg J, Bisgaard T. Surgical treatment for giant incisional hernia: a qualitative systematic review. Hernia. 2014; 18(1):31-8.

10. Malbrain MLNG, Roberts DJ DLI. The role of abdominal compliance, the neglected parameter in critically ill patients - a consensus review of 16. Part 1: Definitions and pathophysiology. Anaesthesiol Intensive Ther. 2014:46:392-405.

11. Blatnik JA, Krpata DM, Pesa NL, Will P, Harth KC, Novitsky YW, et al. Predicting severe postoperative respiratory complications following abdominal wall reconstruction. Plast Reconstr Surg. 2012;130(4):836-41.

12. Malbrain MLNG, Peeters $Y$, Wise R. The neglected role of abdominal compliance in organ-organ interactions. Critical Care. 2016;20:67.

13. Kuteesa J, Kituuka 0 , Namuguzi D, Ndikuno C, Kirunda S, Mukunya $\mathrm{D}$, et al. Intra-abdominal hypertension; prevalence, incidence and outcomes in a low resource setting; a prospective observational study. World J Emerg Surg. 2015;10:57.

14. Chandra R, Jacobson RA, Poirier J, Millikan K, Robinson E SN. Successful non- operative management of intraabdominal hypertension and abdominal compartment syndrome after complex ventral hernia repair: a case series. Am J Surg. 2018; 216(4):819-823.

15. De Keulenaer BL, De Waele JJ, Powell B, Malbrain MLNG. What is normal intra-abdominal pressure and how is it affected by positioning, body mass and positive end-expiratory pressure? Intensive Care Medicine. 2009;35(6):969-76.

16. Oliver-Allen HS, Hunter C, Lee GK. Abdominal compartment syndrome as a rare complication following component separation repair: case report and review of the literature. Hernia. 2015; 19(2): 293-9.

17. Agnew SP, Small W, Wang E, Smith LJ, Hadad I, Dumanian GA. Prospective measurements of intra-abdominal volume and pulmonary function after repair of massive ventral hernias with the components separation technique. Ann Surg. 2010;251(5):981-8.

18. Malbrain MLNG, De Keulenaer BL, Oda J, De Laet I, De Waele JJ, Roberts DJ, et al. Intra-abdominal hypertension and abdominal compartment syndrome in burns, obesity, pregnancy, and general medicine. Anaesthesiol Intensive Ther. 2015;47(3):228-40.

19. Rastogi P, Iyer D, Aneman A, D'Amours S. Intra-abdominal hypertension and abdominal compartment syndrome: pathophysiological and non-operative management. Minerva Anestesiol. 2014; (80):922-32.

20. Dąbrowski W, Kotlinska-Hasiec E, Jaroszynski A, Zadora P, Pilat J, Rzecki Z, et al. Intra-abdominal pressure correlates with extracellular water content. PLoS One. 2015;10(4):e0122193.

21. Holodinsky JK, Roberts DJ, Ball CG, Blaser AR, Starkopf J, Zygun $D A$, et al. Risk factors for intra-abdominal hypertension and abdominal compartment syndrome among adult intensive care unit patients: a systematic review and meta-analysis. Crit Care. 2013; 17(5):R249

22. Luckianow GM, Ellis M, Governale D, Kaplan LJ. Abdominal compartment syndrome: Risk factors, diagnosis, and current therapy. Critical Care Research and Practice. 2012:2012:908169.

23. Santa-Teresa P, Muñoz J, Montero I, Zurita M, Tomey M, ÁlvarezSala $L$, et al. Incidence and prognosis of intra-abdominal hypertension in critically ill medical patients: A prospective epidemiological study. Ann Intensive Care. 2012; 2 Suppl 1:S3.

24. De Waele JJ, Ejike JC, Leppäniemi A, De Keulenaer BL, De laet I, Kirkpatrick AW, et al. Intra-abdominal hypertension and abdominal compartment syndrome in pancreatitis, paediatrics, and trauma. Anestezjol Intens Ter. 2015; 47(3):219-27.

25. Kyoung K-H, Hong S-K. The duration of intra-abdominal hypertension strongly predicts outcomes for the critically ill surgical patients: a prospective observational study. World J Emerg Surg. 2015; 10:22.

26. Adekunle S, Pantelides NM, Hall NR, Praseedom R, Malata CM. Indications and outcomes of the components separation technique in the repair of complex abdominal wall hernias: experience from the cambridge plastic surgery department. Eplasty. 2013;13:e47.

27. Passot G, Villeneuve L, Sabbagh C, Renard Y, Regimbeau JM, Verhaeghe P, et al. Definition of giant ventral hernias: Development of standardization through a practice survey. Int J Surg. 2016; 28:136-40.

28. Tanaka EY, Yoo JH, Rodrigues AJ, Utiyama EM, Birolini D, Rasslan S. A computerized tomography scan method for calculating the hernia sac and abdominal cavity volume in complex large incisional hernia with loss of domain. Hernia. 2010; 14(1):63-9.

29. Anand M, Hajong R, Naku N, Hajong D, Singh KL. Giant inguinal herniae managed by primary repair: A case series. J Clin Diagnostic Res. 2017; 11(2):PR01-PR02.

30. Hasan ZR, Sorensen GB. A Novel Nonoperative Approach to Abdominal Compartment Syndrome After Abdominal Wall Reconstruction. JSLS J Soc Laparoendosc Surg. 2013;17(3):491-4.

31. Parmeggiani D, Gubitosi A, Ruggiero R, Docimo G, Atelli PF, Avenia $\mathrm{N}$. The abdominal compartment syndrome: Review, experience report and description of an innovative biological mesh application. Updates in Surgery. 2011; 63(4):271-5.

32. Pomahac B, Aflaki P. Use of a non-cross-linked porcine dermal scaffold in abdominal wall reconstruction. Am J Surg. 2010; 199(1):22-7.

33. De Santi L, Frigo F, Bruttocao A, Terranova O. Pathophysiology of giant incisional hernias with loss of abdominal wall substance. In: Acta Biomedica de l'Ateneo Parmense. 2003; 74 Suppl 2:34-7.

34. Vidal MG, Weisser JR, Gonzalez F, Toro MA, Loudet C, Balasini C, et al. Incidence and clinical effects of intra-abdominal hypertension in critically ill patients. Crit Care Med. 2008; 36(6):1823-31. 